\title{
PENINGKATAN KETERAMPILAN SOSIAL MELALUI PENERAPAN ATURAN MAIN PADA KEGIATAN BERMAIN DI SENTRA KELOMPOKA2 TK ABA JOGOKARYAN
}

\author{
Oleh: \\ Tsany Nur Farhani \\ PPG SM-3T PG-PAUD UNY 2016 \\ ftsanynurfarhani $\bar{i}$ gmail.com
}

\begin{abstract}
Abstrak
Penelitian ini bertujuan untuk meningkatkan keterampilan sosial anak kelompok A2 di TK ABA Jogokaryan Jogjakarta. Penelitian ini merupakan penelitian tindakan kelas yang dilakukan secara kolaboratif partisipatif dengan menggunakan model penelitian Kurt Lewin. Subjek dalam penelitian ini adalah anak kelompok A2 di TK ABA Jogokaryan Jogjakarta yang berjumlah 15 anak yang terdiri dari 8 anak laki-laki dan 7 anak perempuan. Metode yang digunakan dalam pengumpulan data adalah observasi dan dokumentasi, sedangkan teknik analisis data digunakan secara kualitatif dan kuantitatif. Hasil penelitian menunjukkan penerapan aturan main pada kegiatan bermain di sentra dapat meningkatkan keterampilan sosial anak A2 di TK ABA Jogokaryan Jogjakarta. Peningkatan dari pra tindakan ke Siklus I sebesar 33,3\% dan dari Siklus I ke Siklus II mengalami peningkatan sebanyak 20\%. Anak yang berada pada kriteria Berkembang Sesuai Harapan pada Siklus II sebesar 80\%. Adapun keberhasilan tersebut dilakukan dengan langkah sebagai berikut: (1) menyiapkan media di setiap sentra (2) memberikan kesempatan kepada anak untuk berekspolasi sesuai gagasannya di setiap sentar (3) menerapkan aturan main yang telah disepakati bersama di sentar (4) memberi reward bagi yang mengikuti aturan main di sentra (5) memberi punishment bagi yang belum mengikuti aturan main.
\end{abstract}

Kata kunci: keterampilan sosial, aturan bermain di sentra

\section{Abstract}

The research was carried out to improve students' social skill in group A2 of TK ABA Jogokariyan Yogyakarta and classified as classroom action research. The research used collaborative participation and followed Kurt Lewin's research model. Subjects of the research were 15 students of group A2 in TK ABA Jogokariyan comprising 8 boys and 7 girls. Data was obtained through observation and documentation. The analysis was performed qualitatively and quantitatively. The research result showed that the application of game rules in the central was able to improve the students' social skill. There was $33.3 \%$ increase from before the treatment to the cycle I and $20 \%$ increase from cycle I to cycle II. The procedures of the research were: 1) preparing media in each central, 2) giving chance to students to explore their ideas in each central, 3) employing game rules which earlier had been agreed together in the central, 4) giving reward to those obeying the rules in each central, 5) giving punishment to those disobeying the rules.

Keywords: social skill, game rules in central

PENDAHULUAN

Plato dalam (Ali dan Yeni, 2011: 1.13) berpendapat secara potensial (fitrah) manusia dilahirkan sebagai mahluk sosial (zoon politicon). Salah satu tugas perkembangan awal masa kanak-kanak yang penting adalah memperoleh latihan dan pengalaman pendahuluan yang 
diperlukan untuk menjadi anggota kelompok dalam masa akhir anak-anak.

Carol dan Barbara (2008: 23) menyebutkan anak-anak usia, 3, 4 dan 5 tahun bertumbuh menjadi mahluk sosial. Usia 3 tahun memperlihatkan minat terhadap orang dewasa, usia 4 dan 5 mulai menyukai bersama dengan anak lain.

Aktivitas bermain bisa menjadi salah satu cara untuk mengembangkan keterampilan sosial pada anak. Karena bermain adalah dunia yang paling dekat dengan anak. Selain itu manfaat dari bermain secara signifikan bisa merubah perilaku egosentris anak menjadi lebih sosial.

Proses kegiatan pembelajaran yang dilaksanakan di TK Jogokaryan sudah berupaya untuk menstimulasi aspek perkembangan sosial. Metode pembelajaran sentra yang digunakan di sekolah tersebut memungkinkan anak untuk bisa saling berinteraksi dengan teman di kegiatan main yang telah dirancang guru setiap harinya.

Namun berdasarkan pengamatan yang dilakukan peneliti, terlihat beberapa anak belum memiliki keterampilan sosial yang diharapkan, seperti masih menggunakan kekerasan dengan memukul, menendang, mencubit jika merasa terganggu oleh teman atau saat memecahkan konflik dengan teman, belum mau bergabung dalam kegiatan main, belum dan tertib, serta belum antri saat menunggu giliran.

Maka peneliti tertarik untuk memberikan penguatan pada pembuatan aturan main dikegiatan main di sentra. Walaupun di kelas tersebut sudah dibuat aturan main namun belum terlihat penekanan dalam pelaksanaanya. Maka peneliti mencoba untuk terus menerapkan aturan main di sentra di setiap kegiatan main dengan lebih diberi penekanan dan selalu diulang-ulang setiap harinya.

\section{METODE PENELITIAN Jenis Penelitian}

Jenis penelitian yang digunakan adalah penelitian tindakan kelas Waktu dan Tempat Penelitian

Waktu penelitian dilaksanakan pada semester I, yaitu bulan AgustusNovember tahun ajaran 2016-2017, bertempat di TK ABA Jogokaryan. J1 Jogokaryan MJ III 487 Mantrijeron Yogyakarta.

\section{Target/Subjek Penelitian}

Adapun subjek yang diteliti adalah anak kelompok A2 TK ABA Jogokaryan sebanyak 15 orang. Yang terdiri dari 8 laki-laki dan 7 perempuan.

\section{Prosedur}

1. Observasi Awal

Observasi awal dilakukan untuk memperoleh gambar data awal mengenai keterampilan anak kelompok A2 di TK ABA Jogokaryan.

2. Perencanaan yang meliputi pembuatan RKH, mempersiapkan media, lembar observasi serta kamera untuk mendokumentasikan kegiatan.

3. Pelaksanaan penelitian, yaitu penggunaan aturan dalam kegitan bermain di sentra.

4. Obervasi, dilaksanakan pada saat kegiatan pembelajaran menggunakan lembar obervasi Cheklist dan dokumentasi.

5. Refleksi dilakukan dengan berdiskusi bersama guru kelas tentang kendala yang dihadapi dan merencanakan perbaikan pada pelaksanaan siklus berikutnya atau menghentikan tindakan.

\section{Intrumen, dan Teknik Pengumpulan Data}

Penelitian ini menggunakan dua metode pengumpulan data, yaitu observasi dan dokumentasi. Aspek-aspek keterampilan sosial yang diamati adalah:

1. Bergabung dalam kegiatan main

2. Fokus dan tertib 
3. Antri saat bergiliran

4. Tidak menyakiti teman

Tabel 1. Kisi-kisi Observasi Keterampilan Sosial Anak

\begin{tabular}{|c|c|c|}
\hline Variabel & Indikator & Deskripsi \\
\hline \multirow[t]{4}{*}{$\begin{array}{l}\text { Keterampil } \\
\text { an Sosial } \\
\text { Anak }\end{array}$} & $\begin{array}{l}\text { Bergabung } \\
\text { dalam } \\
\text { kegiatan } \\
\text { main }\end{array}$ & $\begin{array}{l}\text { Anak mau } \\
\text { bergabung dalam } \\
\text { kegiatan main } \\
\text { tanpa bimbingan } \\
\text { guru }\end{array}$ \\
\hline & $\begin{array}{l}\text { Fokus dan } \\
\text { tertib }\end{array}$ & $\begin{array}{l}\text { Anak dapat fokus } \\
\text { dan tertib selama } \\
\text { pembelajaran } \\
\text { (cerita pagi, do'a, } \\
\text { tadarus bersama, } \\
\text { apersepsi) }\end{array}$ \\
\hline & $\begin{array}{l}\text { Antri saat } \\
\text { bergiliran }\end{array}$ & $\begin{array}{l}\text { Anak dapat antri } \\
\text { bergiliran saat } \\
\text { mencuci tangan, } \\
\text { mengambil } \\
\text { minum dan } \\
\text { menggunakan alat } \\
\text { main }\end{array}$ \\
\hline & $\begin{array}{l}\text { Tidak } \\
\text { menyakiti } \\
\text { teman }\end{array}$ & $\begin{array}{l}\text { Tidak melakukan } \\
\text { hal-hal yang dapat } \\
\text { menyakiti teman } \\
\text { (mencubit, } \\
\text { memukul, } \\
\text { menendang) } \\
\end{array}$ \\
\hline
\end{tabular}

\section{Teknik Analisis Data}

Analisis data adalah merangkum data dengan cara yang akurat dan dapat dipertanggungjawabkan sehingga mampu memberikan makna (IGAK Wardhani dan Kuswaya Wihardit, 2008: 5.9). Teknik analisis data yang digunakan dalam penelitian ini adalah deskriptif kuantitatif yaitu dengan cara mendeskripsikan atau menggambarkan kenyataan atau fakta yang diperoleh dengan tujuan untuk mengetahui peningkatan keterampilan sosial anak melalui kegiatan bermain di sentra.

Kemudian data tersebut diinterpretasikan ke dalam empat tingkatan, yaitu:

1. Kriteria belum berkembang (BB) yaitu antara $0 \%-50 \%$

2. Kriteria mulai berkembang (MB) yaitu antara 50,8\% - 66,7\%
3. Kriteria berkembang sesuai harapan (BSH) yaitu antara $67,5 \%-83,3 \%$

4. Kriteria berkembang sangat baik (BSB) yaitu antara $84,1 \%-100 \%$.

\section{HASIL PENELITIAN DAN PEMBAHASAN \\ Kondisi Awal Keterampilan Sosial Anak Pra Tindakan}

Data awal kemampuan anak diperoleh pada waktu peneliti melakukan pengamatan sebelum tindakan. Pengamatan tersebut dilakukan pada bulan Agustus 2016 pada saat kegiatan pembelajaran mulai dari kegiatan awal sampai kegiatan akhir. Berdasarkan hasil pengamatan sebelum tindakan, diketahui bahwa anak kelompok A2 sebagian besar belum memiliki keterampilan sosial yang baik.

Dari pengamatan peneliti terlihat beberapa anak beberapa kali menyakiti teman saat ia merasa tidak nyaman atau bahkan bercanda baik dengan memukul, menendang, mencubit. Itu terjadi beberapa kali mulai saat ikrar pagi sampai dengan pulang. Pada saat pembelajaran akan dimulai beberapa anak tidak mau bergabung dalam lingkaran dan memilih main di luar sentra menggunakan alat main outdoor, guru sudah berupaya membujuk untuk bergabung bersama teman lain, ada yang mau bergabung dan ada yang tidak mau sama sekali. Pada saat cerita pagi, do'a, tadarus bersama dan apersepsi beberapa anak banyak yang tidak fokus dan tertib saat mengikutinya, mereka malah mengobrol dengan temannya. Beberapa kali guru harus mengingatkan untuk fokus dan tertib, beberapa anak mau mengikuti, namun beberapa masih harus terus diingatkan. Saat cuci tangan beberapa anak tidak mau antri untuk mencuci tangan, dia menyerobot, guru sudah mengingatkan untuk antri, beberapa anak menjadi antri dan beberapa lainnya belum mau antri. 
Tabel 2. Rekapitulasi Data Keterampilan Sosial Kelompok A2 Pra Tindakan

\begin{tabular}{|c|c|c|c|c|}
\hline $\begin{array}{l}\mathrm{N} \\
\mathrm{o}\end{array}$ & $\begin{array}{c}\text { Pencapaian } \\
\text { Persentase } \\
\text { Keterampilan Sosial }\end{array}$ & $\begin{array}{c}\text { Jumlah } \\
\text { Anak }\end{array}$ & Persentase & Kriteria \\
\hline 1 & $\begin{array}{l}\text { Anak yang } \\
\text { memperoleh } 0 \% \text { - } \\
50 \% \text { dalam } \\
\text { keterampilan social }\end{array}$ & 9 & $60 \%$ & $\mathrm{BB}$ \\
\hline 2 & $\begin{array}{lr}\text { Anak } & \text { yang } \\
\text { memperoleh } & 50,8 \% \text { - } \\
66,7 \% & \text { dalam } \\
\text { keterampilan sosial }\end{array}$ & 2 & $13,3 \%$ & MB \\
\hline 3 & $\begin{array}{l}\text { Anak yang } \\
\text { memperoleh } 67,5 \% \text { - } \\
83,3 \% \text { dalam } \\
\text { keterampilan sosial }\end{array}$ & 4 & $26,7 \%$ & BSH \\
\hline 4 & $\begin{array}{lr}\text { Anak } & \text { yang } \\
\text { memperoleh } & 84,1 \% \text { - } \\
100 \% & \text { dalam } \\
\text { keterampilan sosial }\end{array}$ & - & - & BSB \\
\hline & Jumlah & 15 & $100 \%$ & \\
\hline
\end{tabular}

\section{Pelaksanan Penelitian Siklus I}

\section{Perencanaan}

Peneliti dan guru telah menyusun rencana pelaksanaan tindakan pada Siklus I dengan memberikan tindakan dengan kegiatan bermain di sentra. Pelaksanaan tindakan Siklus I dilaksanakan selama lima kali pertemuan yaitu pertemuan pertama pada hari Rabu, 24 Agustus 2016, pertemuan kedua pada hari Senin, 29 Agustus 2016, pertemuan ketiga pada hari Kamis, 1 September 2016, pertemuan keempat pada hari Senin, 5 September 2016 dan pertemua kelima pada hari Rabu, 12 oktober 2016. Pada tahap perencanaan peneliti dan guru menentukan tema, sub tema pembelajaran, merencanakan pembelajaran yang tertuang pada $\mathrm{RPPH}$, menentukan indikator keberhasilan, menyusun panduan pelaksanaan pembelajaran dan monitoring penelitian tindakan kelas bagi guru kelas/kolaborator, mempersiapkan media pembelajaran pada setiap sentra, serta mempersiapkan kamera untuk mengambil foto atau gambar anak maupun guru saat proses kegiatan pembelajaran berlangsung sebagai dokumentasi untuk mendukung penelitian, menyiapkan instrumen penilaian berupa lembar observasi untuk mencatat keterampilan sosial yang akan di observasi.

\section{Hasil Observasi}

Selama lima kali tindakan dan pengamatan kegiatan main di sentra peneliti mengamati perkembangan keterampilan sosial anak yang tertuang dalam lembar observasi. Dengan terus mengingatkan aturan main di sentra, keterampilan sosial anak mengalami peningkatan, meskipun belum mencapai harapan peneliti.

Aturan main yang diterapkan diantaranya, aturan main saat ikrar pagi, aturan main saat memasuki sentra, aturan main saat cerita pagi, do'a, tadarus bersama dan apersepsi, aturan main saat toilet training dan minum, aturan main saat di kegiatan main, aturan main saat cuci tangan, aturan main saat recalling, aturan main saat do'a pulang. Berikut data keterampilan sosial anak menggunakan aturan main pada anak kelompok A2 di TK ABA Jogokaryan pada siklus I dapat disajikan dalam bentuk tabel sebagai berikut:

Tabel 4 Rekapitulasi Data Keterampilan Sosial Anak Pada Siklus I

\begin{tabular}{|c|c|c|c|c|}
\hline No & $\begin{array}{c}\text { Pencapaian } \\
\text { Persentase } \\
\text { Keterampilan } \\
\text { Sosial } \\
\end{array}$ & $\begin{array}{c}\text { Jumlah } \\
\text { Anak }\end{array}$ & $\begin{array}{l}\text { Persen } \\
\text { tase }\end{array}$ & Kriteria \\
\hline 1 & $\begin{array}{l}\text { Anak yang } \\
\text { memperoleh } 0 \% \text { - } \\
50 \% \text { dalam } \\
\text { keterampilan sosial }\end{array}$ & 2 & $13,3 \%$ & BB \\
\hline 2 & $\begin{array}{lr}\text { Anak } & \text { yang } \\
\text { memperoleh } & 50,8 \% \\
-\quad 66,7 \% & \text { dalam } \\
\text { keterampilan } & \text { sosial } \\
\end{array}$ & 4 & $26,7 \%$ & MB \\
\hline 3 & $\begin{array}{l}\text { Anak yang } \\
\text { memperoleh } 67,5 \% \\
\text { - } 83,3 \% \text { dalam } \\
\text { keterampilan sosial }\end{array}$ & 9 & $60 \%$ & BSH \\
\hline 4 & $\begin{array}{lr}\text { Anak } & \text { yang } \\
\text { memperoleh } & 84,1 \% \\
-\quad 100 \% & \text { dalam } \\
\text { keterampilan } & \text { sosial } \\
\end{array}$ & - & - & BSB \\
\hline & Jumlah & 15 & $100 \%$ & \\
\hline
\end{tabular}

Keterangan :

BB : Belum Berkembang (0\% - 50\%)

MB : Mulai Berkembang (50,8\% - 66,7\%) 
$\mathrm{BSH}$ : Berkembang Sesuai Harapan (67,5\% $83,3 \%)$

BSB : Berkembang Sangat Baik $(84,1 \%$ $100 \%)$

Berdasarkan tabel 4 di atas dapat disimpulkan keterampilan sosial pada anak kelompok A2 di TK ABA Jogokarya setelah dilakukan tindakan pada siklus I yaitu anak yang memperoleh pencapaian persentase $67,5 \%-83,3 \%$ dalam keterampilan sosial naik menjadi 9 anak atau dengan persentase $60 \%$ (Berkembang sesuai harapan).

Persentase yang dicapai tersebut sudah cukup baik dikarenakan ada peningkatan dari sebelum diadakan tindakan dari 4 anak menjadi 9 anak untuk kriteria BSH (Berkembang sesuai harapan). Namun dalam siklus I ini masih ada beberapa anak yang masih menyakiti teman, belum fokus dan tertib dan masih harus diingatkan saat harus antri.

\section{Refleksi}

Data yang diperoleh melalui pengamatan digunakan sebagai pedoman peneliti dan guru untuk melakukan refleksi pada permasalahan yang muncul sehingga dapat mencari solusi terhadap masalah tersebut. Pencarian solusi ini bertujuan untuk meningkatkan keterampilan sosial anak menggunakan aturan main di sentra untuk merencaakan tindakan yang akan dilakukan pada siklus berikutnya.

Beberapa kendala yang perlu dicari solusi dan perlu adanya peningkatan pada siklus berikutnya yaitu:

a. Penekanan saat menerapkan aturan main belum menggunakan bahasa yang jelas dan tegas.

b. Belum menggunakan reward dan punishment saat menerapkan aturan main.

Peneliti dan guru berdiskusi untuk mencari solusi agar kegiatan pembelajaran pada siklus berikutnya dapat berjalan lancar dan dapat meningkatkan keterampilan sosial anak pada pembelajaran sentra. Solusi dari beberapa kendala tersebut yaitu:

a. Memakai bahasa yang lugas dan tegas sehingga mudah dipahami anak.

b. Menggunakan reward dan punishment sehingga anak menjadi termotivasi dan mulai mengikuti aturan main.

\section{Pelaksanan Penelitian Siklus II}

\section{Perencanaan}

Berdasarkan hasil observasi dan refleksi pada Siklus I peneliti dan guru berdiskusi untuk menyusun perencanaan pelaksanaan tindakan pada Siklus II. Perencanaan meliputi merencanakan program pembelajaran yang dituangkan dalam RKH, mempersiapkan media pembelajaran, mempersiapkan lembar observasi untuk mencatat segala aktivitas selama proses kegiatan belajar mengajar berlangsung yang berisi daftar isian yang mencakup kegiatan anak dalam keterampilan sosial dan mempersiapkan kamera untuk mendokumentasikan proses kegiatan pembelajaran yang digunakan untuk mendukung dalam penelitian dan memperoleh data.

Rencana tindakan yang akan dilakukan pada Siklus II untuk perbaikan yaitu lebih sering mengingatkan kesepatakan main, memberi reward dan punishment bagi yang melanggarnya.

\section{Hasil Observasi}

Pada penelitian Siklus II selama proses pembelajaran menggunakan reward dan punishment serta penekanan di setiap aturan main, anak-anak terlihat jauh lebih fokus dan tertib, walaupun harus diingatkan berkali-kalli. Mereka terlihat lebih antusias untuk bergabung dalam kegiatan main. Anak-anak yang menyakiti teman nya sudah mulai berkurang. Anak-anak sudah bisa antri saat mencuci tangan dan minum. Berikut data keterampilan sosial pada kegiatan bermain di sentra pada anak kelompok A2 di TK ABA Jogokaryan pada penelitian tindakan Siklus II dapat 
disajikan dalam bentuk table sebagai berikut:

Tabel 5. Rekapitulasi Data Keterampilan Sosial Anak Siklus II

\begin{tabular}{|c|c|c|c|c|}
\hline $\begin{array}{c}\mathrm{N} \\
\mathrm{o}\end{array}$ & $\begin{array}{l}\text { Pencapaian Persentase } \\
\text { Keterampilan Sosial }\end{array}$ & $\begin{array}{c}\text { Jumlah } \\
\text { Anak }\end{array}$ & $\begin{array}{c}\text { Persen } \\
\text { tase }\end{array}$ & $\begin{array}{c}\text { Krite } \\
\text { ria }\end{array}$ \\
\hline 1 & $\begin{array}{l}\text { Anak yang memperoleh } \\
0 \%-50 \% \text { dalam } \\
\text { keterampilan social }\end{array}$ & - & - & BB \\
\hline 2 & $\begin{array}{l}\text { Anak yang memperoleh } \\
50,8 \%-66,7 \% \text { dalam } \\
\text { keterampilan sosial }\end{array}$ & 3 & $20 \%$ & MB \\
\hline 3 & $\begin{array}{l}\text { Anak yang memperoleh } \\
67,5 \%-83,3 \% \text { dalam } \\
\text { keterampilan sosial }\end{array}$ & 12 & $80 \%$ & BSH \\
\hline 4 & $\begin{array}{l}\text { Anak yang memperoleh } \\
84,1 \%-100 \% \text { dalam } \\
\text { keterampilan sosial }\end{array}$ & - & - & BSB \\
\hline & Jumlah & 15 & $100 \%$ & \\
\hline
\end{tabular}

Keterangan :

BB : Belum Berkembang (0\% - 50\%)

MB : Mulai Berkembang (50,8\% - 66,7\%)

BSH : Berkembang Sesuai Harapan (67,5\% $83,3 \%$ )

BSB : Berkembang Sangat Baik $(84,1 \%$ $100 \%)$

Berdasarkan table 5 di atas dapat disimpulkan bahwa keterampilan sosial pada anak kelompok A2 di TK ABA Jogokaryan setelah dilakukan siklus II yaitu anak yang memperoleh pencapaian persentase $67,5 \%$ - $83,3 \%$ dalam keterampilan sosial naik menjadi 12 anak atau dengan persentase $80 \%$ (Berkembang Sesuai Harapan).

Berdasarkan data tersebut, maka dapat disimpulkan bahwa keterampilan sosial anak pada kegiatan bermain di sentra pada penelitian tindakan Siklus II dapat dikatakan sudah mencapai indikator keberhasilan yang ditentukan oleh peneliti sehingga kegiatan main di sentra mampu meningkatkan keterampilan sosial anak kelompok A2 di TK ABA Jogokaryan. Data ini menunjukkan bahwa keterampilan sosial pada anak kelompok A2 di TK ABA Jogokaryan apabila dilihat dari persentase pra tindakan, pelaksaanan tindakan Siklus I dan pelaksanaan tindakan Siklus II mengalami peningkatan dan sudah mencapai ketuntasan indikator keberhasilan yang telah direncanakan peneliti. Persentase yang dicapai sudah melebihi dari indikator keberhasilan yaitu 76\%/lebih anak berada pada kriteria BSH.

\section{Refleksi}

Pelaksanaan refleksi pada penelitian tindakan Siklus II dilakukan peneliti dan guru dengan melihat perbandingan persentase jumlah anak yang berada di kriteria BSH atau pencapaian persentase $67,5 \%$ - 83,3\% antara data pra tindakan dan sesudah dilakukan tindakan pada Siklus I dan II. Peningkatan keterampilan sosial pada anak kelompok A2 di TK ABA Jogokaryan pada Siklus II dapat diketahui dengan cara membandingkan perolehan persentase sebelum dilakukan tindakan dan sesudah dilakukan tindakan pada Siklus I dan II. Adapun perbandingannya adalah sebagai berikut:

Tabel 6. Perbandingan Persentase Peningkatan Keterampilan Sosial Anak Pra Tindakan, Siklus I, dan Siklus II pada Kriteria BSH

\begin{tabular}{|c|c|c|c|}
\hline No & Tindakan & Persentase/Kriteria & Peningkatan \\
\hline 1 & $\begin{array}{c}\text { Pra } \\
\text { Tindakan }\end{array}$ & $26,7 \%$ & - \\
\hline 2 & Siklus I & $60 \%$ & $33,3 \%$ \\
\hline 3 & Siklus II & $80 \%$ & $20 \%$ \\
\hline
\end{tabular}

Berdasarkan tabel 6 di atas dapat diketahui adanya peningkatan dari data yang diperoleh sebelum tindakan ke sesudah pelaksanaan tindakan pada Siklus I serta peningkatan dari Siklus I ke Siklus II. Peningkatan sebelum tindakan ke Siklus I sebesar 33,3 \% dan siklus I ke siklus II peningkatannya sebesar $20 \%$. 


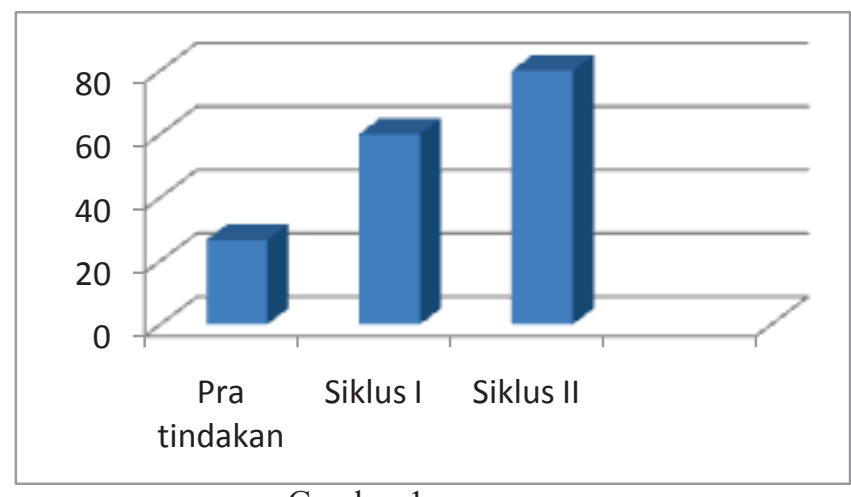

Grafik Rekapitulasi Hasil Keterampilan Sosial Anak Pada Kegiatan Bermain di Sentra

\section{PEMBAHASAN}

Setelah anak kelompok A2 di TK ABA Jogokaryan mendapatkan tindakan untuk meningkatkan keterampilan sosial melalui kegiatan main di sentra selama 2 siklus, hal ini menunjukkan adanya peningkatan pada keterampilan sosial anak. Setelah dilaksanakan Siklus II, keberhasilan yang direncanakan peneliti dapat tercapai dengan hasil yang cukup baik.

Adapun hasil pembahasannya adalah sebagai berikut:

1. Pada Siklus II, sebagian besar anak mencapai keberhasilan dalam keterampilan sosial. Hanya ada 3 anak yang harus terus diingatkan berulang-ulang agar dapat mengikuti aturan main dikarenakan mereka memiliki rentang konsentrasi yang pendek. Hal ini sesuai dengan Petersen (Rasyid, 2009: 159) berpendapat bahwa anak yang memiliki kelemahan berkonsentrasi biasanya ditandai dengan ciri-ciri aktifitas fisik seperti; Gelisah, aktifitas yang berlebihan atau hiper aktif, selalu bergerak tanpa alasan, sangat mudah mengalihkan perhatian, suka berbicara keras, suka membuat keributan dan bersikap impulsif. Jadi anak-anak yang memiliki rentang konsentrasi yang pendek mengalami kesulitan saat guru menerapkan aturan main untuk tertib dan fokus. Sedangkan 12 anak lainnya mampu berkonsentrasi dengan baik sejalan dengan itu Wolfson (2006) mengemukakan bahwa perkembangan konsentrasi pada anak Usia 4,5 - 5 tahun mengalami kematangan. Dia tidak mudah terganggu dan tetap melakukan aktivitas, tanpa perlu istirahat, sampai dia puas bahwa yang dikerjakan itu telah selesai.

2. Keterampilan sosial perlu dimiliki anak sejak dini, hal ini perlu mendapat stimulasi yang tepat agar menjadi bekal anak meenghadapi kehidupan selanjutnya. Masa anak merupakan masa bermain, maka alangkah baiknya jika pembelajaran keterampilan sosial diperoleh anak melalui kegiatan bermain dengan teman. Hal ini serupa dengan pendapat yang dikemukakan oleh Ali dan Yeni (2005: 1.15) bahwa, pengembangan sosial bisa diperoleh melalui bermain. Aktivitas bermain bagi seorang anak memiliki peranan yang cukup besar dalam mengembangkan kecakapan sosialnya sebelum anak mulai berteman. Aktivitas bermain menyiapkan anak dalam menghadapi pengalaman sosialnya

\section{KESIMPULAN DAN SARAN}

\section{Kesimpulan}

Berdasarkan hasil penelitian dan pembahasan, maka peneliti menarik kesimpulan yaitu pembelajaran dengan menggunakan kegiatan main di sentra mampu meningkatkan keterampilan sosial anak di TK ABA Jogokaryan Jogjakarta. Peningkatan tersebut dapat dilihat dan dibuktikan dari adanya peningkatan persentase dari sebelum tindakan, setelah dilakukan tindakan pada Siklus I dan setelah dilakukan tindakan pada Siklus II. Peningkatan dari pra tindakan ke Siklus I sebesar 33,3\% dan dari Siklus I ke Siklus II mengalami peningkatan sebesar $20 \%$. Anak yang berada pada kriteria Berkembang Sesuai Harapan sebelum 
tindakan/pra tindakan sebesar 26,7\%, pada Siklus I sebesar $60 \%$, dan pada Siklus II sebesar $80 \%$.

Adapun keberhasilan tersebut dilakukan dengan langkah-langkah sebagai berikut: (1) mempersiapkan media dan mengkondisikan anak, (2) memberitahukan tema pembelajaran serta menjelaskan secara berulang-ulang aturan main di sentra, (3) memberikan reward saat anak mampu mengukuti aturan main di sentra, (4) ) memberikan punishment saat anak mampu mengukuti aturan main di sentra, dan (5) menjalin kedekatan dengan anak.

\section{Saran}

Berdasarkan kesimpulan dari hasil penelitian di atas, peneliti memberikan saran sebagai berikut:

1. Bagi Guru

Dalam kegiatan main di sentra guru harus lebih tegas mengingatkan aturan main di sentra secara berulang-ulang. Dalam pembelajaran, guru harus mampu menciptakan suasana yang riang dan nyaman bagi anak serta selalu memberikan perhatian dan motivasi baik itu verbal, fisik, ataupun dengan hadiah/ reward. Guru juga selalu menciptakan inovasi-inovasi dalam pembelajaran sehingga anak lebih aktif, antusias, dan cepat menangkap apa yang diajarkan.

2. Bagi Peneliti Selanjutnya
Peneliti selanjutnya harus lebih mampu untuk menguasai kelas, mampu menjelaskan aturan main di sentra dengan lebih menarik sehingga anak sehingga kesadaran untuk mengikuti aturan main lahir dari dalam diri anak bukan merupakan paksaan dari luar.

\section{DAFTAR PUSTAKA}

Ali Nugraha \& Yeni Rachmawati. (2005). Metode pengembangan sosial emosional. Jakarta: Universitas Terbuka.

IGAK Wardhani \& Kuswaya Wihardit. (2008). Penelitian tindakan kelas. Jakarta: Universitas Terbuka.

Rasyid, Harun. (2009). Pengembangan Instrumen asesmen konsentrasi dan perkembangan anak usia dini berbasis model bermain. Disertasi: Tidak Diterbitkan. 